\title{
Quantitative methylation profiling in tumor and matched morphologically normal tissues from breast cancer patients
}

\author{
Ilse Van der Auwera', Catherine Bovie², Cecilia Svensson², Xuan B Trinh', Ridha Limame', Peter van Dam',
} Steven J van Laere ${ }^{1 *}$, Eric A van Marck', Luc Y Dirix', Peter B Vermeulen ${ }^{1}$

\begin{abstract}
Background: In the present study, we determined the gene hypermethylation profiles of normal tissues adjacent to invasive breast carcinomas and investigated whether these are associated with the gene hypermethylation profiles of the corresponding primary breast tumors.

Methods: A quantitative methylation-specific PCR assay was used to analyze the DNA methylation status of 6 genes (DAPK, TWIST, HIN-1, RASSF1A, RARB2 and APC) in 9 normal breast tissue samples from unaffected women and in 56 paired cancerous and normal tissue samples from breast cancer patients.

Results: Normal tissue adjacent to breast cancer displayed statistically significant differences to unrelated normal breast tissues regarding the aberrant methylation of the RASSFIA $(P=0.03), R A R \beta 2(P=0.04)$ and APC $(P=0.04)$ genes. Although methylation ratios for all genes in normal tissues from cancer patients were significantly lower than in the cancerous tissue from the same patient $(P \leq 0.01)$, in general, a clear correlation was observed between methylation ratios measured in both tissue types for all genes tested $(P<0.01)$. When analyzed as a categorical variable, there was a significant concordance between methylation changes in normal tissues and in the corresponding tumor for all genes tested but RASSF1A. Notably, in 73\% of patients, at least one gene with an identical methylation change in cancerous and normal breast tissues was observed.
\end{abstract}

Conclusions: Histologically normal breast tissues adjacent to breast tumors frequently exhibit methylation changes in multiple genes. These methylation changes may play a role in the earliest stages of the development of breast neoplasia.

\section{Background}

Breast cancer is the most frequently diagnosed cancer in women worldwide http://www.cancer.org. Approximately 1.3 million women are diagnosed with breast cancer each year. There are well-understood genetic alterations associated with breast carcinogenesis, including specific gene amplifications, deletions, point mutations, chromosome rearrangements and aneuploidy. In addition to these highly characterized mutations, epigenetic alterations are key contributors to breast carcinogenesis. The most widely studied epigenetic event in

\footnotetext{
* Correspondence: steven.vanlaere@gza.be

${ }^{1}$ Translational Cancer Research Group (Laboratory of Pathology, University of Antwerp/University Hospital Antwerp; Oncology Centre, General Hospital St-Augustinus), 2610 Antwerp, Belgium
}

(C) 2010 Auwera et al; licensee BioMed Central Ltd. This is an Open Access article distributed under the terms of the Creative Commons Attribution License (http://creativecommons.org/licenses/by/2.0), which permits unrestricted use, distribution, and reproduction in any medium, provided the original work is properly cited. breast cancer is the hypermethylation of CpG islands associated with the promoter and first exon regions of several genes [1]. Methylation of CpG islands in gene promoter regions is thought to be especially relevant for the silencing of important growth control genes. For breast cancer, some of the genes reported to undergo hypermethylation are involved in evasion of apoptosis (DAPK, TWIST1, HOXA5), cell cycle regulation ( $p 16$, $C C N D 2)$, cell invasion and metastasis $(C D H 1, A P C)$, DNA repair (BRCA1) and cell signaling (ER and $R A R \beta 2$ ) [2]. These epigenetic alterations occur at an early stage in breast carcinogenesis. High levels of some hypermethylated genes can be detected very early, in the ductal lavage and nipple aspirates of patients with ductal carcinoma in situ and stage I tumors, with methylation 
frequencies comparable with those of more advanced, invasive breast cancers [3].

Hitherto, there has been a focus on the biology of the primary tumor and its immediate precursor lesions rather than on the apparently normal epithelial cells in which the carcinogenic sequence begins. Nevertheless, there is a growing realization that the emergence of focal lesions occurs in association with 'field changes', which can be defined as the presence of cancer causing changes in apparently normal tissue surrounding a neoplasm [4]. The presence of field cancerization has been described in different cancer types, including breast cancer [5]. Previous studies have demonstrated that genetic alterations, such as loss of heterozygosity and allelic imbalance, exist in histologically normal breast tissues immediately adjacent to invasive cancers [6,7]. Recently, normal tissue adjacent to primary breast carcinomas has been shown to exhibit hypermethylation changes in multiple genes that are also present in the primary tumor [8-14]. Some of the early epigenetic changes in histologically normal tissues adjacent to e.g. prostate or colon cancer have been shown to be an age-related event [15-18]. However, in breast cancer, the relationship between methylation changes in normal breast tissues from cancer patients and patients' age has not yet been studied in detail.

Quantitative methylation profiling for the identification and classification of field defects might provide an objective approach for early detection or risk assessment of breast cancer. In fact, DNA methylation in benign breast epithelial cells has been related to a personal history of benign or malignant breast disease and to predicted breast cancer risk in two independent studies [19,20]. Promoter methylation of RASSF1A showed the greatest discrimination between benign samples from women with breast cancer, unaffected high-risk women and unaffected lowrisk women, as defined by the Gail model [19].

In the present study, we used quantitative real-time methylation-specific PCR (qMSP) to quantify the methylation status of 6 genes in matched normal and cancerous tissues from 56 patients with invasive breast cancer: death associated protein kinase (DAPK), TWIST, high in normal$1(H I N-1)$, RAS association domain family protein $1 \mathrm{~A}$ (RASSF1A), retinoic acid binding receptor beta 2 (RAR $\beta 2)$ and adenomatous polyposis coli $(A P C)$. The purposes of this study were: i) to measure the frequency of gene hypermethylation in tumor tissue, normal tissue from breast cancer patients and normal tissue from unaffected patients and ii) to determine whether methylation changes in normal tissues from breast cancer patients are associated with age.

\section{Methods}

\section{Patients and sample collection}

We collected 9 normal breast tissue samples from patients who underwent breast reductive surgery (age range, 25-47 years). None of these samples showed pathological changes. In addition, we collected 56 pairs of matched normal and breast cancer tissue samples from patients with breast cancer (age range, 30-86 years). Additional primary tumor characteristics were recorded by review of pathology files and are listed in Table 1 . Tumors were histologically graded from 1 to 3 according to the Nottingham modification of the Bloom and Richardson histological grading scheme [21]. ER, PR and P53 status were determined by immunohistochemistry. HER2 status was determined according to the College of American Pathologists (CAP) and the American Society of Clinical Oncology (ASCO) joint guideline [22].

All samples were procured at the time of surgery, subjected to an initial gross pathological examination, frozen in liquid nitrogen and then stored in $\mathrm{N}_{2}$ at $-180^{\circ} \mathrm{C}$. Corresponding normal tissues were procured at the most distant site from the resected specimen (distances from the primary tumor were not routinely measured in this

\section{Table 1 Patient characteristics}

\begin{tabular}{|c|c|}
\hline Clinicopathological factors $(\mathrm{N}=56)$ & $\mathrm{N}(\%)$ \\
\hline \multicolumn{2}{|l|}{ T status } \\
\hline 1 & $28(50 \%)$ \\
\hline 2 & $18(32 \%)$ \\
\hline 3 & $7(13 \%)$ \\
\hline 4 & $3(5 \%)$ \\
\hline \multicolumn{2}{|l|}{ Nodal involvement } \\
\hline Negative & $30(54 \%)$ \\
\hline Positive & $26(46 \%)$ \\
\hline \multicolumn{2}{|c|}{ American Joint Committee on Cancer Stage } \\
\hline 1 & $24(43 \%)$ \\
\hline$\|$ & $16(29 \%)$ \\
\hline III & $14(25 \%)$ \\
\hline IV & $2(4 \%)$ \\
\hline \multicolumn{2}{|l|}{ Grade } \\
\hline 1 & 19 (34\%) \\
\hline 2 & $18(32 \%)$ \\
\hline 3 & $19(34 \%)$ \\
\hline \multicolumn{2}{|l|}{ ER status } \\
\hline Negative & $7(13 \%)$ \\
\hline Positive & $48(86 \%)$ \\
\hline Unknown & $1(1 \%)$ \\
\hline \multicolumn{2}{|l|}{ PR status } \\
\hline Negative & $17(30 \%)$ \\
\hline Positive & $39(70 \%)$ \\
\hline \multicolumn{2}{|l|}{ P53 status } \\
\hline Negative & $40(71 \%)$ \\
\hline Positive & $14(25 \%)$ \\
\hline Unknown & $2(4 \%)$ \\
\hline \multicolumn{2}{|l|}{ HER2 status } \\
\hline Negative & $41(73 \%)$ \\
\hline Positive & $15(27 \%)$ \\
\hline
\end{tabular}


study). For each tumor and normal breast tissue sample, a section adjacent to the tissue part used for DNA extraction was stained with haematoxylin and eosin for histological confirmation of the presence or absence of cancer cells. However, tissue sizes were inadequate to perform tissue morphometry on these slides.

Informed consent was obtained from all patients participating in the study. All samples were obtained from Sint-Augustinus (Antwerp, Belgium) in accordance with the institutional policies. All protocols were reviewed and approved by the Ethical Committee of SintAugustinus.

\section{Extraction and sodium bisulphite conversion of DNA}

DNA extractions from breast tissue samples were performed using the QIAamp DNA Mini Kit (Qiagen, Valencia, CA, USA) according to the manufacturer's protocol. DNA samples $(200 \mu \mathrm{l})$ were frozen at $-80^{\circ} \mathrm{C}$ until use. DNA was quantified using a NanoDrop 1000 spectrophotometer (Thermo Scientific, Wilmington, DE, USA) and $1.5 \mu \mathrm{g}$ of DNA was sodium bisulphite-converted using the EZ DNA Methylation Kit (Zymo Research, Orange, CA, USA) according to the manufacturer's instructions.

\section{Quantitative real-time MSP}

The analyte (RASSF1A, RARB2, APC, DAPK, HIN1, TWIST1 and $A C T B)$ quantitations were done in realtime PCR assays using the ABI Prism 7900HT (Applied Biosystems, Foster City, CA, USA). Methylated version of RASSF1A, RAR 32 , APC, DAPK, HIN1 and TWIST1 promoter sequences were detected. $A C T B$ was used as a reference gene in the assay, using primers that are outside any CpG islands. The PCR conditions were $95^{\circ} \mathrm{C}$ for $5 \mathrm{~min}$, followed by 45 cycles of $95^{\circ} \mathrm{C}$ for $30 \mathrm{~s}, 57^{\circ} \mathrm{C}$ for $30 \mathrm{~s}$, and $72^{\circ} \mathrm{C}$ for $30 \mathrm{~s}$, with a final extension cycle of $72^{\circ} \mathrm{C}$ for $5 \mathrm{~min}$ (the annealing temperature was $51^{\circ} \mathrm{C}$ instead of $57^{\circ} \mathrm{C}$ for the $A P C$ assay). Data were collected at the $57^{\circ} \mathrm{C}$ (or $51^{\circ} \mathrm{C}$ ) plateau.

The results were generated using the SDS 2.2 software (Applied Biosystems, Foster City, CA, USA). The copy numbers were calculated based on the linear regression obtained for a standard curve of 8 to $8 \times 10^{5}$ gene copy equivalents, using plasmid DNA containing the bisulphite-modified sequence of interest. CpGenome ${ }^{\mathrm{Tm}}$ Universal methylated and unmethylated DNA (Millipore, Billerica, USA) were included in each experiment as positive and negative controls, respectively.

The amplicons generated during the amplification process were quantified by real-time measurement of the emitted fluorescence (fluorophore: FAM). The ratio between the methylated marker and the independent reference gene $A C T B$ was calculated. This ratio was defined as the test result (test result $=$ copies methylated marker/copies $A C T B \times 1,000)$.

\section{Statistical analysis}

Test results for each gene were analyzed in two ways: as a continuous variable and as a dichotomized variable (according to the maximal methylation ratio observed in normal breast tissues from unaffected women). We used Pearson's X2 or, in the case of low frequencies per cell, Fisher's exact method to test associations between categorical variables. The Mann-Whitney U test or the Wilcoxon signed-rank test was used to assess differences between nonparametric distributed variables. The Kappa statistic was used to assess the agreement between two dichotomous variables. A two-sided $\mathrm{P} \leq 0.05$ was considered to be statistically significant. All statistical calculations were performed using SPSS, version 11.0 (SPSS Inc, Chicago, IL, USA).

\section{Results}

Gene methylation ratios in matched normal and cancerous breast tissue

A total of 6 genes (DAPK, TWIST, HIN-1, RASSF1A, $R A R \beta 2$ and $A P C$ ) was analyzed for promoter methylation in normal breast tissues from 9 reduction mammoplasty specimens and in matched normal and cancerous tissues from 56 breast cancer patients using qMSP. Results for all genes in all cases are presented in Table 2.

Table 2 DNA methylation of 6 genes associated with breast carcinogenesis in normal and cancerous breast tissues.

\begin{tabular}{|c|c|c|c|c|c|}
\hline Gene & $\begin{array}{l}\text { Normal tissue from } \\
\text { unaffected women }(\mathrm{N}=9)\end{array}$ & $\begin{array}{c}\text { Normal tissue from cancer } \\
\text { patients }(\mathrm{N}=56)\end{array}$ & $\begin{array}{l}\text { Cancerous tissue } \\
(\mathrm{N}=56)\end{array}$ & P-value $^{a}$ & P-value $^{b}$ \\
\hline DAPK & $0.47(0.00-2.51)$ & $0.30(0.00-690.19)$ & $0.92(0.00-1445.43)$ & 0.56 & 0.34 \\
\hline TWIST & $0.00(0.00-1.78)$ & $0.00(0.00-388.92)$ & $0.00(0.00-1066.79)$ & 0.06 & 0.03 \\
\hline HIN-1 & $0.00(0.00-0.00)$ & $0.00(0.00-296.26)$ & $199.46(0.00-2627.44)$ & 0.31 & 0.003 \\
\hline RASSFIA & $0.74(0.19-103.25)$ & $11.15(0.00-418.42)$ & $348.80(0.00-1241.21)$ & 0.03 & $<0.001$ \\
\hline$R A R \beta 2$ & $0.00(0.00-0.00)$ & $0.00(0.00-183.29)$ & $0.00(0.00-977.59)$ & 0.04 & 0.07 \\
\hline$A P C$ & $0.00(0.00-0.00)$ & 0.00 (0.00-1992.07) & $163.97(0.00-4481.91)$ & 0.04 & 0.004 \\
\hline
\end{tabular}

\footnotetext{
${ }^{a}$ Comparison between normal tissues from different sources

${ }^{b}$ Comparison between normal tissue from unaffected women and cancerous tissue

Median methylation ratios and range are shown.
} 
Some degree of methylation was detectable in normal breast tissue from unaffected women for 3 of the 6 genes assayed (DAPK, TWIST and RASSF1A), although the ratios of methylation varied considerably for different genes, from a maximal test result of approximately 2 for DAPK and TWIST to a maximal value of 103 in the case of RASSF1A. Compared with the normal breast tissues from unaffected women $(\mathrm{N}=9)$, we observed higher methylation ratios in normal breast tissues from cancer patients $(\mathrm{N}=56)$ for RASSF1A ( $\mathrm{P}=0.03$, Mann Whitney test), RAR $\beta 2$ ( $\mathrm{P}=0.04$, Mann Whitney test) and $A P C(\mathrm{P}=0.04$, Mann Whitney test). Notably, for the RASSF1A gene, the median methylation ratio in normal tissues from cancer patients was 15-fold higher compared with that in normal tissues from unaffected women. For the DAPK, TWIST and HIN-1 genes, there were no significant differences between the normal tissues from different sources. For all genes, the ratios of methylation in cancerous tissue were higher than in normal breast tissue from unaffected women and for 5 genes (TWIST, HIN-1, RASSF1A, APC) these differences were statistically significant (Table 2 ). The methylation ratios of different genes were not independent of each other. Genes for which methylation ratios most closely correlated in cancerous tissues $(\mathrm{N}=56)$ were $R A S S F 1 A$ and HIN-1 $(\mathrm{r}=0.480, \mathrm{P}<0.001)$ and RASSF1A and TWIST $(\mathrm{r}=0.438, \mathrm{P}=0.001)$. Genes for which methylation ratios most correlated in normal tissues from cancer patients $(\mathrm{N}=56)$ were $R A R \beta 2$ and $A P C(\mathrm{r}=0.502$, $\mathrm{P}<0.001)$ and RASSF1A and HIN-1 $(\mathrm{r}=0.485$, $\mathrm{P}<0.001)$.

Next, we compared the methylation ratios for normal and matched cancerous tissue for each breast cancer patient. For all genes, the ratios of methylation in the cancerous tissue significantly exceeded those of normal tissue from the same patient $(\mathrm{P} \leq 0.01$, Wicoxon signedrank test). However, in general, a clear correlation between methylation ratios in normal and cancerous tissues could be detected. Correlation coefficients and corresponding values of significance were: $\mathrm{r}=0.378$ and $\mathrm{P}=0.004$ for DAPK, $\mathrm{r}=0.538$ and $\mathrm{P}<0.001$ for TWIST, $\mathrm{r}=0.371$ and $\mathrm{P}=0.005$ for $H I N-1, \mathrm{r}=0.428$ and $\mathrm{P}=0.001$ for RASSF1A, and $\mathrm{r}=0.491$ and $\mathrm{P}<0.001$ for $A P C$.

As cut-off for scoring a sample as 'hypermethylated', the maximal methylation ratio in the control group (normal breast tissues from unaffected women) was used. The frequency of hypermethylated samples was similar in normal and cancerous breast tissues for DAPK, TWIST and $R A R \beta 2$. However, for $H I N-1, R A S S F 1 A$ and $A P C$, cancerous breast tissues were more frequently hypermethylated than matched normal tissues. The methylation frequencies for cancerous and matched normal tissues were as follows: $27 \%$ and $21 \%$ for $D A P K$
$(\mathrm{P} \mathrm{X}=0.51), 46 \%$ and $36 \%$ for TWIST $\left(\mathrm{P} \mathrm{X}^{2}=0.25\right)$, $59 \%$ and $11 \%$ for $H I N-1$ ( $\left.\mathrm{P} \mathrm{X}^{2}<0.001\right), 77 \%$ and $18 \%$ for RASSF1A ( $\left.\mathrm{P} \mathrm{X}^{2}<0.001\right), 29 \%$ and $34 \%$ for $R A R \beta 2\left(\mathrm{P} \mathrm{X}^{2}\right.$ $=0.54)$ and $55 \%$ and $36 \%$ for $A P C\left(\mathrm{P} \mathrm{X}^{2}=0.04\right)$. Methylation of at least one of the 6 genes tested was present in $87 \%$ of cancerous tissues and $62 \%$ of normal tissues $\left(\mathrm{P} \mathrm{X}^{2}\right.$ $=0.002$ ). Methylation of multiple genes (three or more genes) was detected in $39 \%$ of cancerous tissues compared with $14 \%$ of normal tissues $\left(\mathrm{P} \mathrm{X}^{2}=0.003\right)$. The median number of hypermethylated genes was significantly greater for cancerous tissues than for normal tissues ( 3 in cancerous tissues and 1 in normal tissues; $\mathrm{P}<0.001$, Mann Whitney test) (Figure 1A).

\section{Concordant gene methylation in matched normal and cancerous breast tissue}

For most genes, there was a fair to moderate agreement between methylation in cancerous and matched normal

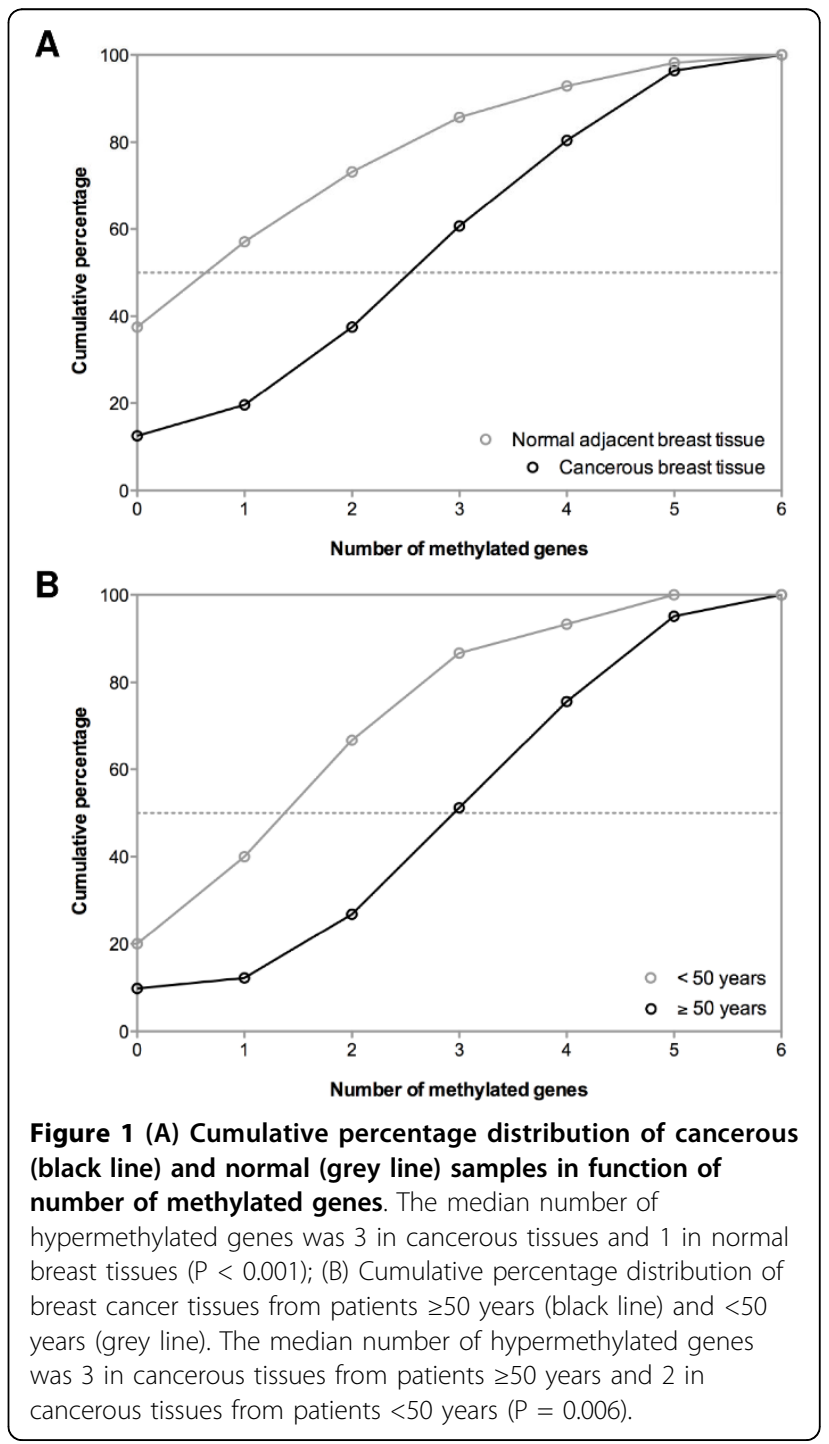


tissues as indicated by the Kappa statistics (Table 3). Only RASSF $1 A$ failed to show statistically significant concordance between the normal tissues and cancerous tissues. Concordant methylation changes in normal and cancerous breast tissues were present in $77 \%$ of cases for $D A P K$, in $68 \%$ of cases for TWIST, in $52 \%$ of cases for $H I N-1$, in $37 \%$ of cases for RASSF1A, in $77 \%$ of cases for $R A R \beta 2$ and in $66 \%$ of cases for $A P C$. When a gene was found hypermethylated in the primary tumor, it was also hypermethylated in the adjacent normal tissue in $47 \%$ of cases for $D A P K$, in $54 \%$ of cases for $T W I S T$, in $18 \%$ of cases for $H I N-1$, in $21 \%$ of cases for RASSF $1 A$, in $69 \%$ of cases for $R A R \beta 2$ and in $52 \%$ of cases for $A P C$. For DAPK, TWIST, RASSF1A, RAR 32 and $A P C$, in some instances (2-14\% of cases), a gene was found hypermethylated in adjacent tissue but not in the corresponding primary tumor. For 41 of 56 (73\%) of patients at least one gene with an identical methylation change in cancerous and normal breast tissues was observed.

\section{Association between DNA methylation changes and clinicopathological factors}

Next, we investigated whether the presence of hypermethylated genes in normal tissues from cancer patients was associated with clinicopathological features of the corresponding primary tumor. The presence of at least one hypermethylated gene in adjacent normal breast tissues was significantly higher when the corresponding primary tumors were expressing ER $\left(\mathrm{P} \mathrm{X}^{2}=0.007\right)$ or PR $\left(\mathrm{P} \mathrm{X}^{2}=0.03\right)$. Furthermore, hypermethylation of RASSF1A was more frequently present in adjacent normal breast tissues from advanced stage breast tumors $\left(\mathrm{P} \mathrm{X}^{2}=0.01\right)$ and hypermethylation of $A P C$ was more frequently present in adjacent normal breast tissues from breast tumors expressing ER $\left(\mathrm{P} \mathrm{X}^{2}=0.04\right)$.

\section{Association between DNA methylation changes and age} Increased DNA methylation in benign breast epithelium has been associated with age [23]. We therefore investigated DNA methylation as a function of age in normal breast tissues from cancer patients and matched breast tumor tissues $(\mathrm{N}=56)$. The mean age of these patients

Table 3 Concordance between the methylation status of cancerous and matched normal breast tissues ( $N=56)$.

\begin{tabular}{lrrrrrr}
\hline \multicolumn{1}{c}{ Gene } & T+ N+ & T- N+ & T- N- & T+ N- & Kappa & P-value \\
\hline DAPK & $7(13 \%)$ & $5(9 \%)$ & $36(64 \%)$ & $8(14 \%)$ & 0.368 & 0.005 \\
TWIST & $14(25 \%)$ & $6(11 \%)$ & $24(43 \%)$ & $12(21 \%)$ & 0.344 & 0.008 \\
HIN-1 & $6(11 \%)$ & $0(0 \%)$ & $23(41 \%)$ & $27(48 \%)$ & 0.154 & 0.03 \\
RASSF1A & $9(16 \%)$ & $1(2 \%)$ & $12(21 \%)$ & $34(61 \%)$ & 0.070 & 0.27 \\
RARB2 & $11(20 \%)$ & $8(14 \%)$ & $32(57 \%)$ & $5(9 \%)$ & 0.462 & $<0.001$ \\
APC & $16(29 \%)$ & $4(7 \%)$ & $21(37 \%)$ & $15(27 \%)$ & 0.342 & 0.006 \\
\hline
\end{tabular}

Abbreviations: $\mathrm{T}$, tumor; $\mathrm{N}$, normal was 58 years (age range, 30-86 years). We did not investigate the association between methylation changes in normal breast tissues from unaffected women and age since the age distribution in this population did not allow for this analysis. For all 6 genes tested, promoter methylation ratios in normal or cancerous breast tissues did not correlate with patients' age.

Next, we compared hypermethylation frequencies in normal and cancerous tissues from women $\geq 50$ years of age $(\mathrm{N}=41)$ and women $<50$ years of age $(\mathrm{N}=15)$. In normal tissues from cancer patients no differences in hypermethylation frequencies for any of the 6 genes tested were observed between both patient groups. However, in cancerous tissues, hypermethylation frequencies of 2 of 6 genes, DAPK $\left(\mathrm{P} \mathrm{X}^{2}=0.005\right)$ and $H I N-1\left(\mathrm{P} \mathrm{X}^{2}=0.003\right)$, were significantly higher in patients $\geq 50$ years of age when compared to patients $<50$ years of age. Furthermore, $49 \%$ of cancerous tissues from patients $\geq 50$ years of age showed multiple gene hypermethylation (three or more genes) compared to only $13 \%$ of cancerous tissues from patients $<50$ years of age $\left(\mathrm{P} \mathrm{X}^{2}=0.02\right)$. Also the median number of hypermethylated genes was significantly higher in cancerous tissues from patients $\geq 50$ years of age: 3 (range, 0-6) versus 2 (range, $0-5)(\mathrm{P}=0.006$, Mann Whitney test) (Figure 1B).

\section{Discussion}

Altered DNA methylation is observed in the early stages of breast carcinogenesis. Both atypical hyperplasia and ductal carcinoma in situ can be distinguished from normal breast tissues based on gene promoter methylation levels [24-29,20,30,12]. Hypermethylation of tumor suppressor genes has also been reported in women who are at risk of developing breast cancer but who do not have cancer $[23,20]$. This abnormal change occurs more frequently in benign breast epithelium of women at high risk for breast cancer than in women at low risk. These findings suggest a possible cancer-predisposing role for DNA methylation.

In the present study, we investigated aberrant methylation of six genes in matched normal and cancerous tissues from 56 patients with breast cancer using a qMSP assay. Genes were selected from the literature for their involvement in breast cancer and have been previously shown to be affected by hypermethylation in breast cancer. We observed no or only low levels of methylation in normal breast tissue samples from unaffected women. Although sample size of normal breast tissues was rather small, also in a previous study analyzing methylation of the $A P C$ gene promoter in 27 normal breast tissues (obtained from reduction mammoplasty specimens), we observed methylation in only three samples [31]. Despite sampling of the normal tissues at the 
site most distant from the primary tumor in the resection specimens, normal tissue adjacent to breast cancer displayed statistically significant differences to unrelated normal breast tissues regarding the aberrant methylation of the RASSF1A, RAR $\beta 2$ and $A P C$ genes. Although methylation ratios in normal tissues from cancer patients were significantly lower than in the cancerous tissue from the same patient, in general, a clear correlation was observed between methylation ratios measured in both tissue types for all genes tested. When analyzed as a categorical variable, there was a statistically significant concordance between methylation changes in normal tissues and in the corresponding tumor for all genes tested but RASSF1A. The observed frequencies of gene methylation in the cancerous samples were highly concordant with previous reports http://www.pubmeth. org. Notably, in $73 \%$ of patients, at least one gene with an identical methylation change in cancerous and normal breast tissues was observed.

One difficulty in methylation studies is the relative purity of the tissue samples in the cells that may be targets for CpG island methylation. Normal breast tissue samples are largely composed of supportive stromal cells and have actually very little epithelial cells. We confirmed the absence of tumor cells in the normal breast tissues on the control slides but unfortunately tissue sizes were inadequate to perform extensive tissue morphometry. We therefore cannot exclude differences in epithelial content between normal breast tissue samples, nor the contamination by ductal carcinoma in situ. Only a handful of other studies have assessed multiple genes in paired cases of cancerous and adjacent normal breast tissues. These studies reported findings similar to ours. Lewis et al. analyzed methylation of 5 genes $(A P C$, RASSF1A, H-cadherin, RAR $\beta 2$ and CCND2) using MSP in 17 breast tumors and matched ipsilateral normal breast tissues [20]. Promoter hypermethylation of at least two of these genes occurred most frequently in breast cancer ( $78 \%$ of samples, $\mathrm{N}=27$ ) followed by normal tissue from cancer patients $(40 \%$ of samples, $\mathrm{N}=$ 17) and at the lowest frequency in normal tissue from unaffected women recruited from a breast cancer risk assessment clinic ( $24 \%$ of samples, $\mathrm{N}=55$ ). For two genes, $R A R \beta 2$ and $A P C$, the differences in hypermethylation frequency between normal breast tissues from unaffected women ( $9 \%$ and $26 \%$, respectively), normal breast tissues from cancer patients (32\% and 33\%, respectively) and cancerous tissues (43\% and 57\%, respectively) were statistically significant. Consistent with these results, our study and the study by Bovenzi et al. reported $R A R \beta 2$ methylation in, respectively, $34 \%$ and $37 \%$ of normal tissue samples from cancer patients $(\mathrm{N}=8)$ [8]. Virmani et al. observed a lower frequency (11\%) of $A P C$ hypermethylation in normal tissues from resections for breast cancer $(\mathrm{N}=28)$ [13]. Fackler et al. examined six pairs of cancerous and adjacent tissue from the surgical margins that were histologically normal for methylation of four genes (RASSF1A, TWIST, cyclin D2 and HIN-1) by qMSP [10]. The cumulative methylation levels of all four genes within adjacent histologically normal breast tissues were significantly lower than in the nearby carcinoma, but significantly higher than those measured in mammoplasty specimens $(N=9)$. In another study, normal tissue samples from the quadrant opposite of the primary tumor $(\mathrm{N}=12)$ showed methylation of each of the 23 genes examined, except for CDKN2 [32]. Using differential methylation hybridization to globally screen CpG islands for methylation alterations in a set of paired cancerous and normal tissues, Yan et al. uncovered a group of loci frequently hypermethylated in normal tissues adjacent to breast tumors [14]. In $~ 70 \%$ of the time, hypermethylation of four of these promoters (RASSF1A, CYP26A1, KCNAB1 and SNCA) was detected in adjacent tissues whenever these genes were found to be hypermethylated in the primary tumor by qMSP. Furthermore, a careful analysis of RASSF1A methylation in normal tissues obtained at a progressively greater distance from the primary tumor suggested a gradient in some but not all of breast samples such that the extent of methylation was greater in the tissue within a $1 \mathrm{~cm}$ circumference of the tumor compared with tissue obtained from $2-4 \mathrm{~cm}$.

\section{Conclusions}

In summary, we clearly demonstrate that histologically normal appearing breast tissues from breast cancer patients exhibit frequent aberrant DNA methylation changes that are concordant with the corresponding tumor. This hypermethylation may represent a large field defect of preneoplastic changes that occurs early in carcinogenesis. The fact that the normal breast tissues lack microscopic evidence of malignancy suggests that these changes are not transforming themselves. However, they might permit the future acquisition and accumulation of other genetic and epigenetic changes that do, in time, lead to malignancy. Similar findings have been reported for colon [33,16,34], lung [35-37] and prostate cancer [18]. In colon and prostate cancer, agerelated methylation changes have been suggested to contribute to the field defect [15-18]. In our study, no association between epigenetic alterations present in normal breast tissues from cancer patients and patients' age was observed. This observation does not support the hypothesis that the observed promoter hypermethylation of the six genes under investigation starts in the normal breast tissue as a function of age. However, a previous study analyzing benign breast epithelial cell samples obtained by fine-needle aspiration biopsy have related 
increasing DNA methylation to increasing age [23]. The age-dependent variation in methylation seems to be gene dependent since Bean et al. did not observe an association between IINK4a/ARF promoter methylation in fine-needle aspiration samples from women at high risk for development of breast cancer and patients' age [38].

If methylation changes do indeed occur earlier than abnormal histologically findings and are associated with subsequent development of breast cancer, then methylation markers in breast samples could potentially identify women at increased risk for breast cancer who might be good candidates for targeted screening and prevention strategies. For women diagnosed with breast cancer, it remains to be determined whether the identification of methylated markers in apparently normal tissue adjacent to tumor might be predictive of clinical outcomes, such as local tumor recurrence.

\section{Acknowledgements}

IVDA is a research assistant of the Fund for Scientific Research Flanders. We would like to thank the technical staff of the Laboratories of Pathology from the General Hospital Sint-Augustinus and the University of Antwerp for technical assistance.

\section{Author details}

'Translational Cancer Research Group (Laboratory of Pathology, University of Antwerp/University Hospital Antwerp; Oncology Centre, General Hospital St-Augustinus), 2610 Antwerp, Belgium. ${ }^{2}$ OncoMethylome Sciences SA, Centre Hospitalier Universitaire, 4000 Liège/Sart Tilman, Belgium.

\section{Authors' contributions}

IVDA: carried out the isolation experiments, performed the statistical analysis, drafted the manuscript. CB and CS: carried out the PCR experiments. RL, XT, PVD, SVL, EVM, PV and LD: conceived of the study and participated in the design and coordination. All authors read and approved the final manuscript.

\section{Competing interests}

The authors declare that they have no competing interests.

Received: 23 July 2009 Accepted: 12 March 2010

Published: 12 March 2010

\section{References}

1. Esteller M: Cancer epigenetics: DNA methylation and chromatin alterations in human cancer. Adv Exp Med Biol 2003, 532:39-49.

2. Li S, Rong M, lacopetta B: DNA hypermethylation in breast cancer and its association with clinicopathological features. Cancer Lett 2006, 237:272-280.

3. Krassenstein R, Sauter E, Dulaimi E, Battagli C, Ehya H, Klein-Szanto A, Cairns P: Detection of breast cancer in nipple aspirate fluid by CpG island hypermethylation. Clin Cancer Res 2004, 10:28-32.

4. Slaughter DP, Southwick HW, Smejkal W: Field cancerization in oral stratified squamous epithelium; clinical implications of multicentric origin. Cancer 1953, 6:963-968.

5. Ushijima T: Epigenetic field for cancerization. J Biochem Mol Biol 2007, 40:142-150.

6. Deng G, Lu Y, Zlotnikov G, Thor AD, Smith HS: Loss of heterozygosity in normal tissue adjacent to breast carcinomas. Science 1996, 274:2057-2059.

7. Ellsworth DL, Ellsworth RE, Love B, Deyarmin B, Lubert SM, Mittal V, Hooke JA, Shriver CD: Outer breast quadrants demonstrate increased levels of genomic instability. Ann Surg Oncol 2004, 11:861-868.
8. Bovenzi V, Le NL, Cote S, Sinnett D, Momparler LF, Momparler RL: DNA methylation of retinoic acid receptor beta in breast cancer and possible therapeutic role of 5-aza-2'-deoxycytidine. Anticancer Drugs 1999, 10:471-476.

9. Dammann R, Yang G, Pfeifer GP: Hypermethylation of the cpG island of Ras association domain family $1 \mathrm{~A}$ (RASSF1A), a putative tumor suppressor gene from the 3 p21.3 locus, occurs in a large percentage of human breast cancers. Cancer Res 2001, 61:3105-3109.

10. Fackler MJ, McVeigh M, Mehrotra J, Blum MA, Lange J, Lapides A, Garrett E, Argani P, Sukumar S: Quantitative Multiplex Methylation-Specific PCR Assay for the Detection of Promoter Hypermethylation in Multiple Genes in Breast Cancer. Cancer Res 2004, 64:4442-4452.

11. Toyooka KO, Toyooka S, Virmani AK, Sathyanarayana UG, Euhus DM, Gilcrease M, Minna JD, Gazdar AF: Loss of expression and aberrant methylation of the $\mathrm{CDH} 13$ (H-cadherin) gene in breast and lung carcinomas. Cancer Res 2001, 61:4556-4560.

12. Umbricht CB, Evron E, Gabrielson E, Ferguson A, Marks J, Sukumar S: Hypermethylation of 14-3-3 sigma (stratifin) is an early event in breast cancer. Oncogene 2001, 20:3348-3353.

13. Virmani AK, Rathi A, Sathyanarayana UG, Padar A, Huang CX, Cunnigham HT, Farinas AJ, Milchgrub S, Euhus DM, Gilcrease M, Herman J, Minna JD, Gazdar AF: Aberrant methylation of the adenomatous polyposis coli (APC) gene promoter $1 \mathrm{~A}$ in breast and lung carcinomas. Clin Cancer Res 2001, 7:1998-2004

14. Yan PS, Venkataramu C, Ibrahim A, Liu JC, Shen RZ, Diaz NM, Centeno B, Weber F, Leu YW, Shapiro CL, Eng C, Yeatman TJ, Huang THM: Mapping Geographic Zones of Cancer Risk with Epigenetic Biomarkers in Normal Breast Tissue. Clin Cancer Res 2006, 12:6626-6636.

15. Ahuja N, Li Q, Mohan AL, Baylin SB, Issa JP: Aging and DNA methylation in colorectal mucosa and cancer. Cancer Res 1998, 58:5489-5494.

16. Issa JP, Ottaviano YL, Celano P, Hamilton SR, Davidson NE, Baylin SB: Methylation of the oestrogen receptor $\mathrm{CpG}$ island links ageing and neoplasia in human colon. Nat Genet 1994, 7:536-540.

17. Issa JP, Vertino PM, Boehm CD, Newsham IF, Baylin SB: Switch from monoallelic to biallelic human IGF2 promoter methylation during aging and carcinogenesis. Proc Natl Acad Sci USA 1996, 93:11757-11762.

18. Kwabi-Addo B, Chung W, Shen L, Ittmann M, Wheeler T, Jelinek J, Issa JP: Age-related DNA methylation changes in normal human prostate tissues. Clin Cancer Res 2007, 13:3796-3802.

19. Euhus DM, Bu D, Milchgrub S, Xie XJ, Bian A, Leitch AM, Lewis CM: DNA methylation in benign breast epithelium in relation to age and breast cancer risk. Cancer Epidemiol Biomarkers Prev 2008, 17:1051-1059.

20. Lewis CM, Cler LR, Bu DW, Zochbauer-Muller S, Milchgrub S, Naftalis EZ, Leitch AM, Minna JD, Euhus DM: Promoter Hypermethylation in Benign Breast Epithelium in Relation to Predicted Breast Cancer Risk. Clin Cancer Res 2005, 11:166-172.

21. Elston CW, Ellis IO: Pathological prognostic factors in breast cancer. I. The value of histological grade in breast cancer: experience from a large study with long-term follow-up. Histopathology 1991, 19:403-410.

22. Wolff AC, Hammond ME, Schwartz JN, Hagerty KL, Allred DC, Cote RJ, Dowsett M, Fitzgibbons PL, Hanna WM, Langer A, McShane LM, Paik S, Pegram MD, Perez EA, Press MF, Rhodes A, Sturgeon C, Taube SE, Tubbs R, Vance GH, van de Vijver M, Wheeler TM, Hayes DF: American Society of Clinical Oncology/College of American Pathologists guideline recommendations for human epidermal growth factor receptor 2 testing in breast cancer. J Clin Oncol 2007, 25:118-145.

23. Euhus DM, Bu D, Milchgrub S, Xie XJ, Bian A, Leitch AM, Lewis CM: DNA methylation in benign breast epithelium in relation to age and breast cancer risk. Cancer Epidemiol Biomarkers Prev 2008, 17:1051-1059.

24. Futscher BW, O'Meara MM, Kim CJ, Rennels MA, Lu D, Gruman LM, Seftor RE, Hendrix MJ, Domann FE: Aberrant methylation of the maspin promoter is an early event in human breast cancer. Neoplasia 2004, 6:380-389

25. Holst CR, Nuovo GJ, Esteller M, Chew K, Baylin SB, Herman JG, Tlsty TD: Methylation of p16(INK4a) promoters occurs in vivo in histologically normal human mammary epithelia. Cancer Res 2003, 63:1596-1601.

26. Hoque MO, Prencipe M, Poeta ML, Barbano R, Valori VM, Copetti M, Gallo AP, Brait M, Maiello E, Apicella A, Rossiello R, Zito F, Stefania T, Paradiso A, Carella M, Dallapiccola B, Murgo R, Carosi I, Bisceglia M, Fazio VM, Sidransky D, Parrella P: Changes in CpG islands promoter 
methylation patterns during ductal breast carcinoma progression. Cancer Epidemiol Biomarkers Prev 2009, 18:2694-2700.

27. Lee JS: GSTP1 promoter hypermethylation is an early event in breast carcinogenesis. Virchows Arch 2007, 450:637-642.

28. Lee JS, Fackler MJ, Teo WW, Lee JH, Choi C, Park MH, Yoon JH, Zhang Z, Argani P, Sukumar S: Quantitative promoter hypermethylation profiles of ductal carcinoma in situ in North American and Korean women: Potential applications for diagnosis. Cancer Biol Ther 2008, 7:1398-1406.

29. Lehmann U, Langer F, Feist H, Glockner S, Hasemeier B, Kreipe H: Quantitative Assessment of Promoter Hypermethylation during Breast Cancer Development. Am J Pathol 2002, 160:605-612.

30. Subramaniam MM, Chan JY, Soong R, Ito K, Ito Y, Yeoh KG, Salto-Tellez M, Putti TC: RUNX3 inactivation by frequent promoter hypermethylation and protein mislocalization constitute an early event in breast cancer progression. Breast Cancer Res Treat 2009, 113:113-121.

31. Auwera Van der I, Van Laere SJ, Bosch Van den SM, Eynden Van den GG, Trinh BX, van Dam PA, Colpaert CG, van Engeland M, Van Marck EA, Vermeulen PB, Dirix LY: Aberrant methylation of the Adenomatous Polyposis Coli (APC) gene promoter is associated with the inflammatory breast cancer phenotype. Br J Cancer 2008, 99:1735-1742.

32. Jeronimo C, Monteiro P, Henrique R, Dinis-Ribeiro M, Costa I, Costa VL, Filipe L, Carvalho AL, Hoque MO, Pais I, Leal C, Teixeira MR, Sidransky D: Quantitative hypermethylation of a small panel of genes augments the diagnostic accuracy in fine-needle aspirate washings of breast lesions. Breast Cancer Res Treat 2008, 109:27-34.

33. Belshaw NJ, Elliott GO, Foxall RJ, Dainty JR, Pal N, Coupe A, Garg D, Bradburn DM, Mathers JC, Johnson IT: Profiling CpG island field methylation in both morphologically normal and neoplastic human colonic mucosa. Br J Cancer 2008, 99:136-142

34. Shen L, Kondo Y, Rosner GL, Xiao L, Hernandez NS, Vilaythong J, Houlihan PS, Krouse RS, Prasad AR, Einspahr JG, Buckmeier J, Alberts DS, Hamilton SR, Issa JP: MGMT promoter methylation and field defect in sporadic colorectal cancer. J Natl Cancer Inst 2005, 97:1330-1338.

35. Belinsky SA, Palmisano WA, Gilliland FD, Crooks LA, Divine KK, Winters SA, Grimes MJ, Harms HJ, Tellez CS, Smith TM, Moots PP, Lechner JF, Stidley CA, Crowell RE: Aberrant promoter methylation in bronchial epithelium and sputum from current and former smokers. Cancer Res 2002, 62:2370-2377.

36. Feng $\mathrm{Q}$, Hawes $S E$, Stern JE, Wiens $L$, Lu H, Dong ZM, Jordan CD, Kiviat NB, Vesselle H: DNA methylation in tumor and matched normal tissues from non-small cell lung cancer patients. Cancer Epidemiol Biomarkers Prev 2008, 17:645-654.

37. Guo M, House MG, Hooker C, Han Y, Heath E, Gabrielson E, Yang SC, Baylin SB, Herman JG, Brock MV: Promoter hypermethylation of resected bronchial margins: a field defect of changes?. Clin Cancer Res 2004, 10:5131-5136.

38. Bean GR, Bryson AD, Pilie PG, Goldenberg V, Baker JC Jr, Ibarra C, Brander DM, Paisie C, Case NR, Gauthier M, Reynolds PA, Dietze E, Ostrander J, Scott V, Wilke LG, Yee L, Kimler BF, Fabian CJ, Zalles CM, Broadwater G, TIsty TD, Seewaldt VL: Morphologically normal-appearing mammary epithelial cells obtained from high-risk women exhibit methylation silencing of INK4a/ARF. Clin Cancer Res 2007, 13:6834-6841.

\section{Pre-publication history}

The pre-publication history for this paper can be accessed here: [http://www.biomedcentral.com/1471-2407/10/97/prepub]

doi:10.1186/1471-2407-10-97

Cite this article as: Van der Auwera et al:: Quantitative methylation profiling in tumor and matched morphologically normal tissues from breast cancer patients. BMC Cancer 2010 10:97.

\section{Submit your next manuscript to BioMed Central and take full advantage of:}

- Convenient online submission

- Thorough peer review

- No space constraints or color figure charges

- Immediate publication on acceptance

- Inclusion in PubMed, CAS, Scopus and Google Scholar

- Research which is freely available for redistribution

Submit your manuscript at www.biomedcentral.com/submit
C Biomed Central 